\title{
Cutaneous mastocytosis in the adult: what lies beneath
}

\author{
LilianaTorres, Francisco Bento Soares, Diana Pereira Anjos, Mari Mesquita \\ Centro Hospitalar do Tâmega e Sousa. Portugal
}

\begin{abstract}
Mastocytosis is a disorder characterized by clonal mast cell proliferation and accumulation within various organs, most commonly, the skin. Adult-onset mastocytosis is highly suggestive of a systemic involvement and the cases limited to the skin are uncommon. The authors report a 61-year-old male with pruritus associated with hyperpigmented maculopapular skin lesions and a positive Darier's sign. The skin biopsy revealed spindle mast cells infiltrations. The bone marrow study was normal. He started on $\mathrm{H} 1$ antihistamines with significant clinical improvement.
\end{abstract}

Keywords: Mastocytosis. Mast cells. Darier's sign.

\section{INTRODUCTION}

Mastocytosis is a rare heterogeneous group of hematopoietic disorders characterized by increased accumulation of mast cells in one or more organs. The most frequently involved are the skin but bone marrow, gastrointestinal tract, liver, spleen and lymph nodes may also be implicated ${ }^{1}$. The incidence is estimated in 1 in 1000 to 8000 patients. Adults who develop mastocytosis often have a systemic disease form at the time of diagnosis; the cutaneous subtypes account for less than $5 \%$ of cases $^{2}$.

\section{CASE REPORT}

A 61-year-old male, without any known diseases or medication, present with generalized pruritic rash for the past 2 years. He denied any other symptoms. The physical examination showed hyperpigmented maculopapular lesions on the trunk and limbs (Figures 1a and 1b).

Darier's sign was positive. The rest of the physical exam was irrelevant. Apart from an erythrocyte sedimentation rate of $11 \mathrm{~mm} / \mathrm{h}$, complete blood cell count, blood glucose, renal and hepatic functions, sodium, potassium, total and ionized calcium were within normal ranges. Chest radiography, abdominal ultrasound and bone densitometry had no alterations. Histopathology of the skin showed perivascular infiltration of the upper dermis consisting of moderate mononuclear inflammatory infiltrates with increased number of spindle mast cells. Bone marrow aspirate was normocellular. He started with oral cetirizine $5 \mathrm{mg}$ bid and loratadine 10mg id with significant clinical improvement. He didn't report for regular check-ups.

\section{DISCUSSION}

In 1869, Nettleship and Tay described a rare form of urticaria with pigmented papular lesions, later termed as urticaria pigmentosa by Sangster in 1878. After mast cells were described by Paul Ehrlich in 1879, the disease was classified as mastocytosis. Until 1949, it was believed that mastocytosis was only a cutaneous disease, but then Ellis described involvement of visceral organs as well ${ }^{3}$.
Figure 1A. Hyperpigmented maculae on the back

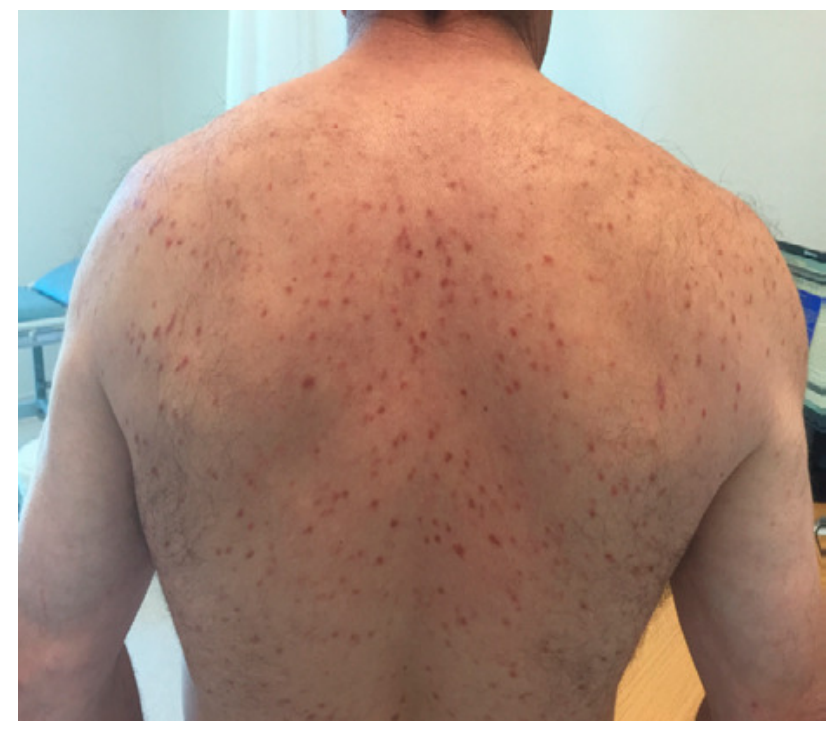

Figure 1B. A close-up of the back lesions

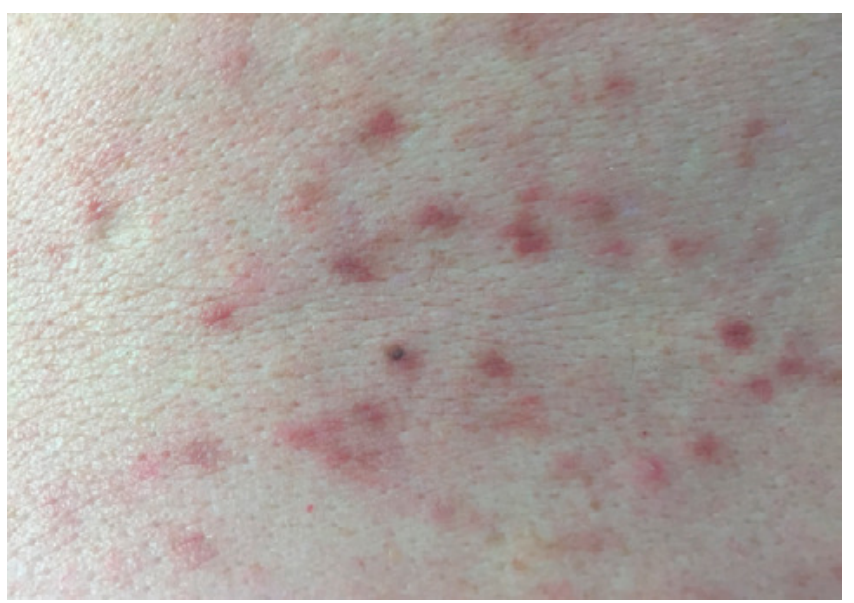


Human mast cells originate from pluripotent cells (CD34+) in the bone marrow and migrate, through the bloodstream, to a specific tissue where they differentiate into two subgroups based on their structures, biochemistry and functions ${ }^{4}$ : mucosal and connective tissue mast cells.

Release of mast cell-derived mediators, such as histamine, prostaglandins, leukotrienes, tumor necrosis factor, interleukins and platelet activating factors may lead to a variety of symptoms and signs such as erythema, edema, pruritus, urticaria, bronchoconstriction, headache, flushing, nasal stuffiness, dizziness, tachycardia, hypotension, syncope, anorexia, nausea, vomiting, increased gastric acidity, abdominal pain and diarrhea ${ }^{5}$. Classic signs such as Darier's sign and dermographism are due to the local release of these mediators ${ }^{6}$.

Although a number of classification schemes have been given for mast cell disease, the WHO classification seems to be more practical and useful for characterizing the disorder? It was divided in two main types, cutaneous and systemic, as described in Table 1, and classified into different subtypes.

Cutaneous mastocytosis describes forms of mastocytosis limited to the skin, in the absence of involvement of other organs. Skin lesions may be subdivided into urticaria pigmentosa, maculopapular cutaneous mastocytosis, diffuse cutaneous mastocytosis and mastocytoma of the skin.

Systemic mastocytosis involves an extracutaneous site, most commonly the bone marrow and in some cases, the gastrointestinal (Gl) tract. The subtypes include indolent systemic mastocytosis, systemic mastocytosis with an associated hematologic non-mast cell lineage disease, aggressive systemic mastocytosis, mast cell leukemia, mast cell sarcoma and extracutaneous mastocytoma ${ }^{3}$.

The aim of mastocytosis therapy is to remove or reduce the symptoms. Treatment involves combining $\mathrm{H} 1$ antihistamines (for pruritus, flushing, urticaria) and $\mathrm{H} 2$ antihistamines (to reduce acidity, diarrhea and other Gl manifestations) ${ }^{9}$. Daily oral mast cell-stabilisers mitigate onset and frequency of cutaneous and Gl symptoms. Systemic corticosteroids are used in ascites, malabsorption, and severe skin disease (bullous). PUVA therapy is used for persistent urticaria pigmentosa in adults for cosmetic improvement ${ }^{10}$.

Cutaneous mastocytosis that develops in adulthood tends to persist over time but has a benign prognosis. Rare cases of progression to aggressive forms such as mast cell sarcoma and mast cell leukemia have been reported and are associated with a poor outcome.

To detect disease progression a yearly monitoring is recommended with serum tryptase levels (which reflect mast cell burden); complete blood cell count (to rule out hematologic malignancies); serum chemistry panel to monitor liver involvement and electrolyte imbalances and bone densitometry (yearly if documented osteopenia or osteoporosis and every 3 years if normal bone density).

\section{REFERENCES}

1. Mehta S, Masatkar V, Khare AK, Mittal A, Gupta LK. Blaschkoid mastocytosis. Indian J Dermatol Venereol Leprol. 2015;81(1):72-3.

2. Wolff K, Komar M, Petzelbauer P. Clinical and histopathological aspects of cutaneous mastocytosis. Leuk Res 2001; 25:519.

3. Swerdlow S, Campo E, Harris NL, Jaffe ES, Pileri SA, Stein H. WHO classification of tumours of haematopoietic and lymphoid tissues. Lyon: International Agency for Research and Cancer (IARC); 2008. p. 54-63.

4. Alto WA, Clark I. Cutaneous and systemic manifestations of mastocytosis. Am Fam Physician 1999; 59:3059-60.

5. Longley J, Duffy TP, Kohn S. The mast cell and mast cell disease. J Am Acad Dermatol 1995, 32:545-61.

6. Surjushe A, Jindal S, Gote P, Saple D. Darier sign. Indian J Dermatol Venereol Leprol 2007:363-4.

7. Vardiman JW, Harris NL, Brunning RD. The World Health Organization (WHO) classification of the myeloid neoplasms. Blood 2002; 100:2292-302.

8. Longley J, Duffy TP, Kohn S. The mast cell and mast cell disease. J Am Acad Dermatol 1995, 32:545-61.

9. Miner PB. The role of the mast cell in clinical gastrointestinal disease with special reference to systemic mastocytosis. J Invest Dermatol 1991, 96:40S-44S.

10. Rodríguez-Granados MT, Carrascosa JM, Gárate T, Gómez-Díez S, GuimaraensJuantorena D. Consensus document on bath-PUVA therapy. The Spanish Photobiology Group of the Spanish Academy of Dermatology and Venereology. Actas Dermosifiliogr 2007, 98(3):164-70.

11. Auquit-Auckbur I, Lazar C, Deneuve S, Guillemet C, Cordel N, Blanchard F et al Malignant transformation of mastocytoma developed on skin mastocytosis into cutaneous mast cell sarcoma. Am J Surg Pathol 2012; 36:779.

Table 1

\begin{tabular}{l}
\hline Cutaneous mastocytosis \\
\hline Skin lesions with typical clinical findings of urticaria pigmentosa, maculopapular cutaneous \\
mastocytosis, diffuse cutaneous mastocytosis or solitary mastocytoma \\
+ \\
Mast cell infiltrates in a multifocal or diffuse pattern in histopathological study of the skin \\
+ \\
Absence of features/criteria of systemic mastocytosis \\
\hline Systemic mastocytosis \\
\hline Major criterion \\
\hline $\begin{array}{l}\text { Multifocal, dense infiltrates of mast cells ( } \geq 15 \text { mast cells in aggregates) detected in sections } \\
\text { of bone marrow and/or other extracutaneous organ(s). }\end{array}$ \\
\hline Minor criteria \\
\hline $\begin{array}{l}\text { In biopsy sections of bone marrow or other extracutaneous organs, }>25 \% \text { of the mast cells in } \\
\text { the infiltrate are spindle-shaped or have atypical morphology or of all mast cells in bone } \\
\text { marrow aspirate smears, }>25 \% \text { are immature or atypical. }\end{array}$ \\
\hline $\begin{array}{l}\text { Detection of an activating point mutation at codon } 816 \text { of } K I T \text { in bone marrow, blood or } \\
\text { another extracutaneous organ }\end{array}$ \\
\hline $\begin{array}{l}\text { Mast cells in bone marrow, blood or other extracutaneous organs express CD2 and/or CD25 } \\
\text { in addition to normal mast cell markers }\end{array}$ \\
\hline $\begin{array}{l}\text { Serum total tryptase persistently exceeds } 20 \mathrm{ng} / \mathrm{mL} \text { (unless there is an associated clonal myeloid disorder, in } \\
\text { which case this parameter is not valid). }\end{array}$ \\
\hline
\end{tabular}

